\title{
On the food of the Eurasian pygmy owl (Glaucidium passerinum) in Slovakia
}

\author{
K potrave kuvička vrabčieho (Glaucidium passerinum) na Slovensku
}

\author{
Karol ŠOTNÁR, Samuel PAČENOVSKÝ \& Ján OBUCH
}

\begin{abstract}
Data on the food of the Eurasian pygmy owl in Slovakia was collected in 1999-2014 at 12 breeding locations in 7 mountain ranges of the Western Carpathian Mts and 1 range belonging to the Eastern Carpathian Mts. The basis of the evaluation of the food spectrum of prey of G. passerinum was the collection of pellets, osteological remnants and feathers from birds beneath nest cavities and roosting places of females in the months of May to July, that is, in the period of feeding young in the nest. Overall samples of food from 12 nests at elevations of 650-1,260 m a.s.l. were collected; from the largest of the three nests in the upper Nitra Region, from one nest in the Západné Tatry Mts and from three nests in the Volovské vrchy Mts. We compared these data with existing published data from Slovakia. A higher share of birds $(65.0 \%)$ was found in the obtained material than mammals $(34.8 \%)$. In the samples from 12 locations 10 species of mammals and 33 species of birds were found among the 377 individual prey samples. Among mammals, forest species of rodents predominated: Clethrionomys glareolus (22.8\%) and Apodemus flavicollis (6.6\%). The species Microtus arvalis (2.7\%) was less abundant than in the stores of food from the Chočské vrchy Mts (35.4\%). From the broad spectrum of songbirds, no species exceeded a presence of 7\%. Species from the families Sylviidae, Turdidae, Paridae and Fringillidae were more numerous, while the species Phoenicurus phoenicurus, Motacilla alba, Carduelis cannabina, Dendrocopos minor and Passer domesticus were among the more uncommon prey. In total 582 individual prey were determined from the food remnants of G. passerinum in Slovakia (present study and other published studies). The species Clethrionomys glareolus occurred with a higher dominance than average in the pellets of G. passerinum in the mountains which border the region of the upper Nitra. In the Belianské Tatry Mts the most abundant rodent species was Terricola subterraneus, while in the mountains of eastern Slovakia the yellow-necked mouse Apodemus flavicollis was most often hunted, and of the songbirds, the coal tit Periparus ater. Among songbirds hunted near the breeding grounds of G. passerinum in the Považský Inovec Mts the collared flycatcher Ficedula albicollis was the most numerous. Among the most numerous songbirds which are evenly represented in all compared areas were: Regulus sp., Certhia familiaris, Poecile montanus and Cyanistes caeruleus.
\end{abstract}

Abstrakt: Údaje o potrave kuvička vrabčieho na Slovensku boli zbierané v rokoch 1999 - 2014 na 12 hniezdnych lokalitách v 7 pohoriach Západných Karpát a 1 pohorí patriacom k Východnám Karpatom. Základom vyhodnotenia potravného spektra koristi G. passerinum bol zber vývržkov, osteologických zvyškov a peria z vtákov pod hniezdnymi dutinami i odpočinkovými miestami samíc v mesiacoch máj až júl, teda v období kŕmenia mlád’at na hniezde. Celkovo boli odobraté vzorky potravy od 12 hniezd v nadmorských výškach 650 - 1260 m n. m.; z toho najväčšie od troch hniezd na Hornom Ponitrí, z jedného hniezda v Západných Tatrách a z troch hniezd vo Volovských vrchoch. Tieto dáta sme porovnali s už publikovanými údajmi z územia Slovenska. V získanom materiáli bol determinovaný vy̌ší podiel vtákov $(65,0 \%)$ než cicavcov $(34,8 \%)$. V súbore z 12 lokalít sa medzi 377 jedincami koristi zistilo 10 druhov cicavcov a 33 druhov vtákov. Medzi cicavcami prevažovali lesné druhy hlodavcov: Clethrionomys glareolus (22,8 \%) a Apodemus flavicollis (6,6 \%). Microtus arvalis $(2,7 \%)$ bol menej početný než v zásobárňach potravy z Chočských vrchov $(35,4 \%)$. Z bohatého spektra spevavcov žiaden druh nepresahoval dominanciu $7 \%$. Početnejšie boli druhy z čel'adí Sylviidae, Turdidae, Paridae a Fringillidae; z nezvyčajnejších druhov koristi boli zistené aj druhy Phoenicurus phoenicurus, Motacilla alba, Carduelis cannabina, Dendrocopos minor a Passer domesticus. Spolu bolo na Slovensku zo zvyškov potravy G. passerinum určených 582 jedincov koristi (táto štúdia a d’alšie už publikované práce). S vyššou dominanciou, než je sumárny priemer, sa vyskytoval Clethrionomys glareolus vo vývržkoch G. passerinum v pohoriach, ktoré ohraničujú región Hornej Nitry. V Belianskych Tatrách bol najpočetnejším hlodavcom druh Terricola subterraneus, v pohoriach východného Slovenska bola častejšie lovená ryšavka Apodemus flavicollis, zo spevavcov sýkorka Periparus ater. Medzi spevavcami lovenými pri hniezdení G. passerinum v Považskom Inovci bol početnejší muchárik Ficedula albicollis. K najpočetnejším spevavcom, ktoré sú rovnomerne zastúpené vo všetkých porovnávaných oblastiach, patria: Regulus sp., Certhia familiaris, Poecile montanus a Cyanistes caeruleus.

Key words: Glaucidium passerinum, breeding season, food, Slovakia

Karol Šotnár, Raptor Protection of Slovakia, Školská 17/12, SK-972 17 Kanianka, Slovakia. E-mail: karol_sotnar@post.sk. Samuel Pačenovský, Slovak Ornithological Society/BirdLife Slovakia, Tatranská 2, SK-040 01 Košice, Slovakia. 
E-mail: pacenovsky@vtaky.sk

Ján Obuch, Botanická záhrada Univerzity Komenského, SK-03815 Blatnica, Slovakia. E-mail: obuch@rec.uniba.sk.

Aknowledgements: The authors would like to acknowledge to Dušan Karaska, Alexander Kürthy, Richard Galáš, Leonidas Prešinský and Vladimír Slobodník for cooperation in location of nests and collecting food-samples of Eurasian pygmy owls.

\section{Introduction}

The Eurasian pygmy owl (Glaucidium passerinum) is a species with a Palaearctic type of distribution, where it inhabits in particular coniferous and mixed forests in the taiga and mountain forests (del Hoyo et al. 1999). An isolated population, probably a post-glaciation relict, occurs in the mountains of Central Europe, from boreal altitude zones of the Alps, the Jura Mts and the Vosges Mts through lower Germany and the Czech uplands and along the entire ridge of the Carpathian Mts. Isolated populations also occur in the Balkans (Mikkola \& Sackl 1997). In Slovakia, breeding grounds are located from $310 \mathrm{~m}$ a.s.l. in the Tríbec Mts up to the tree line of the forest. However, they also commonly breed in the higher mountains. The highest placed nest thus far found was located at an altitude of $1450 \mathrm{~m}$ a.s.1. (Pačenovský 2002, Pačenovský \& Šotnár 2010). In the past it was considered to be a rare breeder and there were only a few specific finds of nests. After 1980 knowledge on the distribution of the species improved (Danko 1988, Pačenovský 1990, Pačenovský \& Kürthy 1991, Pačenovský 2002, Pačenovský \& Shurulinkov 2008, Pačenovský \& Šotnár 2010).

In Slovakia only smaller samples of analysed material on the food of the Eurasian pygmy owl have thus far been published. The first work comes from the Belianske Tatry Mts (Klaus et al. 1982). In eastern Slovakia, in the Volovské vrchy Mts and at Čierna hora Mts, Pačenovský (1990) monitored two nests and assessed food from them. Later the consumption of food and activity of the Eurasian pygmy owl in breeding seasons was also evaluated (Pačenovský 1993). Material from food stores which the Eurasian pygmy owl make throughout the year in nesting boxes and in the natural cavities in trees was collected in northern Slovakia in the Chočské vrchy Mts and Nízke Tatry Mts (Mikusek et al. 2001). Upon monitoring the breeding of Glaucidium passerinum in the Strážovské vrchy Mts, Šotnár (2009) also presents the qualitative composition of prey. The aim of this work is to contribute to the improving knowledge on the food ecology of $G$. passerinum in Slovakia during breeding seasons.

\section{Material and methods}

Data on the food of G. passerinum in Slovakia were collected from 1999-2014 near nest cavities in the Považský Inovec Mts, Súl'ovské vrchy Mts, Strážovské vrchy Mts, Vtáčnik Mts, Žiar Mts, Skorušinské vrchy Mts, Volovské vrchy Mts and the Laborecká vrchovina Uplands. For collection of the material we used a known characteristic of $G$. passerinum, namely the cleaning out of nest cavity, after fledging of young birds, of food remnants, feathers and fur of prey, and from pellets, described by several authors (Mikkola 1983, Schönn 1980).

1) Nemečky, Považský Inovec Mts, 722 m a.s.l. (Fig. 1). An atypical breeding location: predominately beech forests with spruce trees coppices, a breeding stump placed on an open clearing almost without trees. The collection of pellets was done in 2014 .

2) Babkov, Súl'ovské vrchy Mts, $600 \mathrm{~m}$ a.s.l. Linden-maple debris forests occur here on a limestone sub-base and relict pine forests. Collections of pellets were made in 2007.

3) Locality Hvizdák near the village of Tužina in the Strážovské vrchy Mts (Fig. 2). Beech vegetation with spruce, maple and fir trees, $700 \mathrm{~m}$ a.s.l. Collections of food samples were done in 1999, 2005, 2009, 2010, 2012 and 2013 beneath several nest cavities.

4) Locality Chvojnica in the Strážovské vrchy Mts (Fig. 3). Beech forests with a mix of spruce and fir, 750 $\mathrm{m}$ a.s.1., collections of food were made in 2014 .

5) Hradec, Kuncl'ová, in the Vtáčnik Mts, $700 \mathrm{~m}$ a.s.l. A nest cavity in a spruce tree, forest stand of spruce-maple-beech. Collections of food samples were made in 1999 and 2005.

6) Kl'ačno, in the Žiar Mts, $674 \mathrm{~m}$ a.s.l. Nest in a maple tree, in spruce, maple and beech forest, samples collected in 2010.

7) Ondrašová, Žiar Mts, 700 m a.s.1., spruce, maple, beech biotope. Samples collected in 2012.

8) Oravice, Západné Tatry Mts, locality above Šufák, sub-alpine spruce forest, $1260 \mathrm{~m}$ a.s.l. Food samples collected by a nest in 2005 .

9) Kojšovská hol'a, Volovské vrchy Mts (Fig. 4), 

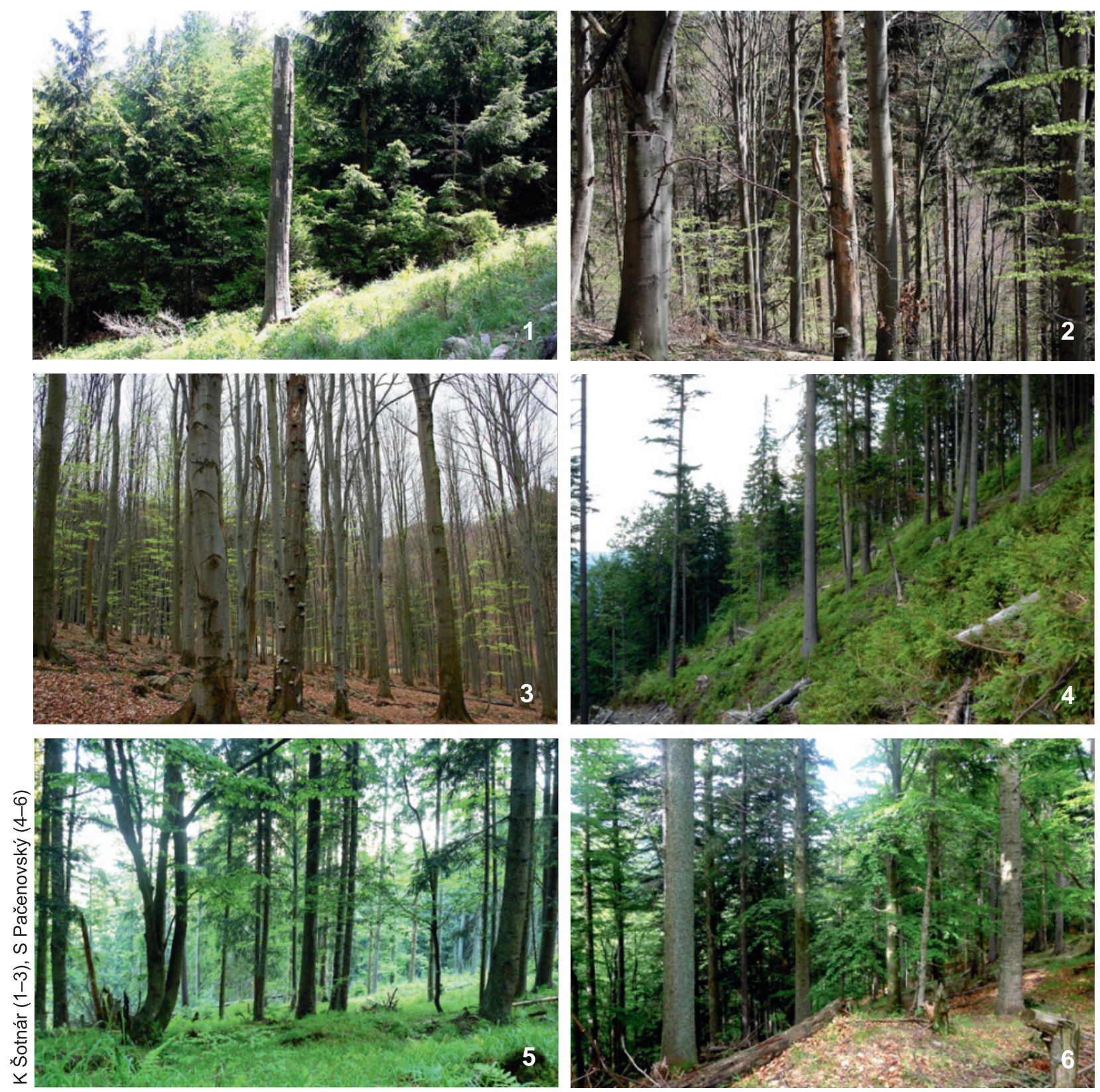

Fig. 1-6. Breeding biotopes of European pygmy owl: Považský Inovec Mts, nesting tree at the locality Nemečky (1); Strážovské vrchy Mts, Tužina - Hvizdák, nesting tree (2), Chvojnica, (3); Volovské vrchy Mts, Kojšovská hol’a (4), Tupý vrch Mt. (5), and Stará Voda (6).

Obr. 1 - 6. Hniezdne biotopy kuvička vrabčieho: Považský Inovec, hniezdny strom na lokalite Nemečky (1); Strážovské vrchy, Tužina - Hvizdák, hniezdny strom (2), Chvojnica (3); Volovské vrchy, Kojšovská hol'a (4), Tupý vrch (5) a Stará Voda (6).

1050 m a.s.l., old mountain spruce-fir-beech forest. Samples collected near a nest in 2011.

10) Štós, Tupý vrch, Volovské vrchy Mts (Fig. 5), $1000 \mathrm{~m}$ a.s.1., spruce-fir-beech forest, more extensive logging in the surroundings. Sample collections from nest cavities for analysis of food come from 2010 and 2011.

11) Stará Voda, Suchý vrch, Volovské vrchy Mts (Fig. 6). Fir-beech forest, $800 \mathrm{~m}$ a.s.l. Collections of food samples from nest come from 2013 and 2014. 
12) Komárnická jedlina, Laborecká vrchovina Uplands, nest cavity in a beech tree, fir-beech forest, 550 $\mathrm{m}$ a.s.l. Samples collected in 2013 .

The size of the samples differed, or the number of prey samples from individual localities were varied. The number of determined samples of prey from individual localities is shown in Table 1, where results of analyses of food samples from these locations are presented. The largest samples were collected from localities no. 1 (Považský Inovec Mts, 23 samples); no. 3 and 4 (Strážovské vrchy Mts, $37+116=153$ samples); no. 8 (Západné Tatry Mts, 21 samples); and no. 9-11 (Volovské vrchy Mts, $19+87+34=140$ samples). From other localities/mountain ranges only smaller samples were available: no. 2 (Súl'ovské vrchy Mts, 6 samples); no. 5 (Vtáčnik Mts, 15 samples); no. 6 and 7 (Žiar Mts, $11+4=15$ samples); no. 12 (Laborecká vrchovina Mts, 4 samples).

The basis of the evaluation of the spectrum of prey of $G$. passerinum was the collection of pellets, osteological remains and feathers from birds beneath nest cavities and roosting sites of females in the months of May through July, that is, in the period of feeding of young in the nest. Overall, new material was collected from 12 breeding sites at elevations from $650-1,260 \mathrm{~m}$ a.s.l. The food samples were collected in particular by the first and second authors of this work, with the exception of those from the Súl'ovské vrchy Mts, which were gathered by V. Slobodník and those from Oravice, which were collected by D. Karaska. Pellets from one collection were processed together in a $5 \%$ solution of $\mathrm{NaOH}$, which dissolved the feathers and fur. Mammals were determined based on the cranial parts of the skull. With the absence of the jawbones the number of bones from the limbs of mammals was presented. Birds were determined according to beaks and the humerus, tarsometatarsus and metacarpal bones. In addition the feathers of prey were determined, particularly by use of the wing and tail feathers, and in some cases it was also possible to use contour feathers in this regard. Feathers used for determination came from prey and were collected freely beneath the nest cavities (Fig. 7); feather remains located in pellets were not used for determining prey. The abundance of species in the sample was determined from the most numerous determined bone. Species of birds determined by feathers were attributed in the case of their absence in osteological remnants from pellets.

New data on food of the Eurasian pygmy owl from Slovakia were assessed together with older published results of analysis of the food of Glaucidium passerinum from Slovakia from 1982-2001 (Chočské vrchy Mts and the Nízké Tatry Mts, Mikusek et al. 2001, Volovské vrchy Mts, Kamenný hrb and Čierna hora, Vysoký vrch, Pačenovský 1990, 1993; Belianske Tatry Mts, Klaus et al. 1982). The results of breeding and non-breeding periods are compared with published results from Central Europe (Germany, Czech Republic, Poland, Hungary). Older, already published results of analysis of food of the Eurasian pygmy owl are presented in Table 2.

Samples from Slovakia and Central Europe (11 areas: 1 - Slovakia, breeding season, 2 - Chočské vrchy Mts, non-breeding season, Mikusek et al. 2001, 3 Szögliget, NP Aggtelek, Schmidt \& Pačenovský 2011, 4 - Česko-Moravská vysočina Uplands, Mikusek et al. 2001, 5 - Třeboň Region, Mikusek et al. 2001, 6 - ك̆umava Mts, Mikusek et al. 2001, 7 - Český les Mts, Mikusek et al. 2001, 8 - Bayerischer Wald Mts, Scherzinger 1974, 9 - Westerzgebirge Mts, Schönn 1976, 10 - Stolowe gory Mts, Mikusek et al. 2001, 11 Bialowieza, Mikusek et al. 2001) are presented in the form of modified tables, in which the sequence of the prey species and the compared areas are ordered on the basis of similarity of marked differences from the mean (MDFM) values (Obuch 2001). Blocks of species with positive differences $(1+, 2+)$ in the scope of this same species across localities are highlighted with a solid line. Samples in the results tables are grouped according to similarity and the order is assigned to columns and blocks according to the determining of the species with positive MDFM values. These blocks are bound by continuous lines. Species with negative differences (1-, $2-)$ are also shown; however, these are not assigned into blocks. The numerical values in the tables are presented in absolute values with the exception of the last column of the table, where the relative values of the dominant prey are listed. Areas without notable differences are shown in the last columns. The most abundant species without significant differences, i.e. with an equal representation in the compared areas, are shown beneath the dashed line. The diversity index $H^{\prime}$ is used, calculated according to the work of Shannon \& Weaver (1949).

\section{Results and discussion}

In the newly collected data, presented in Tab. 1, material collected around nests during the time of raising young is determined exclusively. Upon analysis of the food of Glaucidium passerinum we found a higher share of birds (65.0\%; Fig. 8) than mammals (34.8\%). A total of 10 species of mammals and 33 species of birds were 


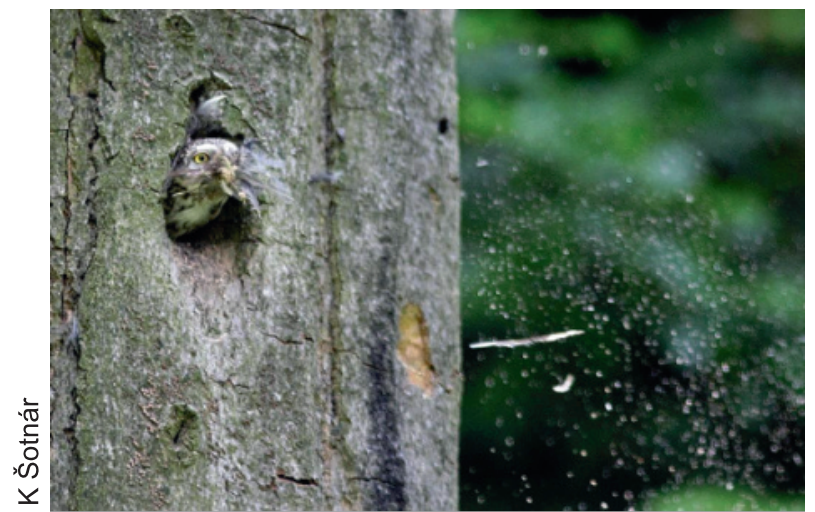

Fig. 7 A female cleaning the nest cavity.

Obr. 7. Samica čistí dutinu.

found among the 377 individual pieces of prey from 12 localities. Two forest rodents predominated among the mammals: the bank vole Clethrionomys glareolus $(22.8 \%)$ and the yellow-necked mouse Apodemus flavicollis (6.6\%). The common vole Microtus arvalis $(2.7 \%)$ is less abundant than in the food samples from the Chočské vrchy (35.4\%). From the rich spectrum of songbirds no species surpassed a dominance of $7 \%$. Species from the families Sylviidae, Turdidae, Paridae and Fringillidae are more numerous. Among the more notable species of birds found in the food spectrum were Dendrocopos minor (Strážovské vrchy Mts), Sylvia borin, Passer domesticus (Strážovské vrchy Mts), Loxia curvirostra (upper Nitra), Phoenicurus phoenicurus, Motacilla alba, Carduelis cannabina (Volovské vrchy Mts), Anthus pratensis (Vtáčnik Mts) and Sylvia communis (eastern Slovakia). The Eurasian pygmy owl rarely hunts lizards or insects.

In summary, from published results on the food of Glaucidium passerinum from Slovakia (Tab. 2) the proportional representation of mammals $(57.6 \%)$ is higher than the share of birds $(42.0 \%)$ in the 205 pieces of prey examined. The highest representation of mammals comes from analysis of the food stores in the Chočské vrchy (Mikusek et al. 2001).

Because we are almost entirely lacking specific observations of hunting behaviour, we can only judge some hunting techniques indirectly on the basis of our knowledge of the avifauna of studied nesting sites of $G$. passerinum. Thus, for example, it seems that some pygmy owls in the Volovské vrchy Mts could hunt singing males of Phoenicurus phoenicurus. This is today a relatively rare species of songbird throughout



Fig. 8. A female with great tit prey at a nest cavity (Nemečky, Považský Inovec Mts).

Obr. 8. Samica s korist'ou sýkorkou vel'kou pri dutine (Nemečky, Považský Inovec).

Slovakia; however, here and there it does appear in the Volovské vrchy Mts, where it is also found in the food of $G$. passerinum, and its early morning vocal activity (song) may fall directly during the peak of the activity of the pygmy owl at the break of day. Other species, like the common linnet, the meadow pipit and the white wagtail, in view of their absence from the studied sites, were evidently hunted by the Eurasian pygmy owl so that it sometimes also captured migrating birds and birds only randomly flying over the mountain ridges. In the case of the Hvizdák locality near the village of Tužina in the Strážovské vrchy Mts it is assumed that the pygmy owl hunted the house sparrow, which was found in the food, near the village or directly within the village, because this breeding site is only $1 \mathrm{~km}$ away from the edge of the village. In the forest here is a significant amount of clear-cut areas, since extraction has been taking place over in the last two years. The nest of the Eurasian pygmy owl is placed about $50 \mathrm{~m}$ below the ridge and the nearest clear-cut is located immediately on the opposite side of the ridge. It can be assumed that the pygmy owl flies across the ridge to hunt on this clearcut, where the species Sylvia borin, S. atricapilla and Prunella modularis and all three species of the genera Phylloscopus occur, as they are likewise found in the food spectrum of this pair and their young.

Young birds, songbirds in particular, make up a relatively high share in the food of G. passerinum. This is associated with the relatively easy accessibility of such food at the time of maturing of young pygmy owls, when food consumption is at its highest. From 10 food collections coming from 3 nests of G. passerinum studied in Slovakia (Volovské vrchy Mts) in 2010-2014, 
Tab. 1. Data on the food of G. passerinum found in from 1999 up through 2014 in 12 localities in Slovakia. Numerical values in the table are presented in absolute values; only in the last column is presented the relative dominance of prey.

Tab. 1. Údaje o potrave G. passerinum zistené v rokoch 1999 až 2014 na 12 lokalitách na Slovensku. Číselné hodnoty v tabul'ke sú uvedené $v$ absolútnych hodnotách, iba v poslednom stĺpci sú uvedené relatívne hodnoty dominancie koristi.

\begin{tabular}{|c|c|c|c|c|c|c|c|c|c|c|c|c|c|c|}
\hline $\begin{array}{l}\text { samples / vzorky } \\
\text { taxa / taxón }\end{array}$ & 1 & 2 & 3 & 4 & 5 & 6 & 7 & 8 & 9 & 10 & 11 & 12 & $\sum$ & $\%$ \\
\hline Sorex araneus & & & & 1 & & & & & 1 & & & & 2 & 0.53 \\
\hline Sorex minutus & & & & & & & & & 1 & & & & 1 & 0.27 \\
\hline Muscardinus avellanarius & & & & & & & & & & 1 & & & 1 & 0.27 \\
\hline Sicista betulina & & & & & & & & & & 1 & & & 1 & 0.27 \\
\hline Mus cf. musculus & & & & 1 & & & & & & & & & 1 & 0.27 \\
\hline Apodemus flavicollis & 1 & & 3 & 3 & & 1 & & 1 & 4 & 9 & 3 & & 25 & 6.63 \\
\hline Apodemus sylvaticus & & & & 2 & & & & & & & & & 2 & 0.53 \\
\hline Clethrionomys glareolus & 1 & 3 & 14 & 37 & 1 & 1 & & 5 & 5 & 14 & 4 & 1 & 86 & 22.81 \\
\hline Terricola subterraneus & & & & 1 & & & & 1 & & & & & 2 & 0.53 \\
\hline Microtus arvalis & & 2 & & & 2 & 1 & 4 & 1 & & & & & 10 & 2.65 \\
\hline Mammalia & 2 & 5 & 17 & 45 & 3 & 3 & 4 & 8 & 11 & 25 & 7 & 1 & 131 & 34.75 \\
\hline Dendrocopos minor & & & & 1 & & & & & & & & & 1 & 0.27 \\
\hline Anthus pratensis & & & & & 1 & & & & & & & & 1 & 0.27 \\
\hline Motacilla alba & & & & & & & & & & 3 & & & 3 & 0.80 \\
\hline Prunella modularis & & & & 4 & & & & & & & 1 & & 5 & 1.33 \\
\hline Sylvia communis & & & & & & & & & & 1 & & 2 & 3 & 0.80 \\
\hline Sylvia borin & & & & 1 & & & & & & & & & 1 & 0.27 \\
\hline Sylvia atricapilla & & & & 3 & 1 & 1 & & & & & 2 & & 7 & 1.86 \\
\hline Phylloscopus trochilus & & & & 4 & & & & 1 & & & & & 5 & 1.33 \\
\hline Phylloscopus collybita & & & 2 & 4 & 1 & 1 & & & & 3 & 1 & & 12 & 3.18 \\
\hline Phylloscopus sibilatrix & & & & 1 & 1 & & & & & & & 1 & 3 & 0.80 \\
\hline Regulus sp. & 3 & & 2 & 2 & & 1 & & 2 & 1 & 3 & 3 & & 17 & 4.51 \\
\hline Muscicapa striata & & & & 1 & & & & 1 & & & & & 2 & 0.53 \\
\hline Ficedula albicollis & 6 & & & & & & & & & & & & 6 & 1.59 \\
\hline Saxicola torquata & & & & & & 1 & & & & & & & 1 & 0.27 \\
\hline Phoenicurus phoenicurus & & & & & & & & & & 1 & 1 & & 2 & 0.53 \\
\hline Erithacus rubecula & 1 & & & 7 & & 1 & & 1 & 1 & 3 & 2 & & 16 & 4.24 \\
\hline Aegithalos caudatus & & & & & & & & & & 4 & 3 & & 7 & 1.86 \\
\hline Parus major & 2 & & 2 & 3 & 1 & 1 & & & & 3 & & & 12 & 3.18 \\
\hline Periparus ater & & & & & & & & & & 13 & 5 & & 18 & 4.77 \\
\hline Cyanistes caeruleus & 2 & & & 4 & 2 & & & & 1 & 1 & & & 10 & 2.65 \\
\hline Lophophanes cristatus & & & & & & & & & & 1 & 1 & & 2 & 0.53 \\
\hline Poecile palustris & & & & 7 & & & & & & 2 & & & 9 & 2.39 \\
\hline Poecile montanus & 3 & & 7 & & & 1 & & & & 1 & 4 & & 16 & 4.24 \\
\hline Sitta europaea & & & & 4 & & & & & 2 & 4 & & & 10 & 2.65 \\
\hline Certhia familiaris & 1 & & 2 & 3 & & & & 4 & & 5 & & & 15 & 3.98 \\
\hline Troglodytes troglodytes & & & 2 & 2 & & & & & & 6 & & & 10 & 2.65 \\
\hline Emberiza citrinella & & 1 & & & & & & & & 1 & 1 & & 3 & 0.80 \\
\hline Fringilla coelebs & 1 & & 1 & 9 & 3 & 1 & & 2 & 1 & 5 & 3 & & 26 & 6.90 \\
\hline Carduelis spinus & & & & 2 & & & & 2 & & & & & 4 & 1.06 \\
\hline Carduelis cannabina & & & & & & & & & 1 & & & & 1 & 0.27 \\
\hline Pyrrhula pyrrhula & & & & 2 & & & & & 1 & & & & 3 & 0.80 \\
\hline Loxia curvirostra & & & & 3 & 1 & & & & & & & & 4 & 1.06 \\
\hline Passer domesticus & & & & 2 & & & & & & & & & 2 & 0.53 \\
\hline Passeriformes indet. & 2 & & 2 & 2 & & & & & & 2 & & & 8 & 2.12 \\
\hline Aves & 21 & 1 & 20 & 71 & 11 & 8 & 0 & 13 & 8 & 62 & 27 & 3 & 245 & 64.99 \\
\hline Hymenoptera & & & & & 1 & & & & & & & & 1 & 0.27 \\
\hline$\sum$ & 23 & 6 & 37 & 116 & 15 & 11 & 4 & 21 & 19 & 87 & 34 & 4 & 377 & 100.00 \\
\hline
\end{tabular}

Samples - date of collection / Vzorky - dátum zberu: 1 - Nemečky, Považský Inovec Mts, 27 May 2014,2 - Babkov, Súlovské skaly Cliffs, 4 May 2007, leg. V. Slobodník, 3 - Chvojnica, Strážovské vrchy Mts, 7 June 2014, 4 - Tužina, Strážovské vrchy Mts, 14 June 1999 + 18 May 2005 + 19 June 2009 + 8 June 2010 + 20 April 2012 + 16 April 2013, 5 - Handlová, Vtáčnik Mts, 26 June 1999 + 5 April 2005, 6 - Klačno, Žiar Mts, 10 June 2010, 7 - Ondrašová, Žiar Mts, 25 September 2012, 8 - Oravice, Skorušinské vrchy Mts, 26 May 2005, 9 - Kojšovská hol'a, Volovské vrchy Mts, 26 June $2011+10$ July 2011, 10 - Tupý vrch, Volovské vrchy Mts, 18 June $2010+3$ July $2010+12$ June $2011+20$ June $2011+26$ June 2011, 11 - Stará Voda, Volovské vrchy Mts, 21 July $2013+11$ June 2014 + 27 June 2014, 12 - Komárnická jedlina, Laborecká vrchovina Uplands, 10 June 2013. 
Tab. 2. Slovakia, published data on the food of Glaucidium passerinum. Numerical values in the table are presented in absolute values.

Tab. 2. Slovensko, publikované údaje o potrave Glaucidium passerinum. Číselné hodnoty $v$ tabul'ke sú uvedené $v$ absolútnych hodnotách.

\begin{tabular}{|c|c|c|c|c|c|}
\hline $\begin{array}{l}\text { mountain range / pohorie } \\
\text { taxa / taxón }\end{array}$ & 1 & 2 & 3 & $\sum$ & $\%$ \\
\hline Sorex araneus & 4 & & 1 & 5 & 2.44 \\
\hline Sorex minutus & 4 & 1 & & 5 & 2.44 \\
\hline Neomys fodiens & & & 1 & 1 & 0.49 \\
\hline Micromys minutus & 1 & & & 1 & 0.49 \\
\hline Apodemus flavicollis & 1 & 2 & & 3 & 1.46 \\
\hline Clethrionomys glareolus & 29 & 4 & 5 & 38 & 18.54 \\
\hline Terricola subterraneus & 6 & & 6 & 12 & 5.85 \\
\hline Microtus arvalis & 45 & 2 & & 47 & 22.93 \\
\hline Microtus agrestis & 3 & & 3 & 6 & 2.93 \\
\hline Mammalia & 93 & 9 & 16 & 118 & 57.56 \\
\hline Prunella modularis & & 2 & 1 & 3 & 1.46 \\
\hline Sylvia curruca & & 1 & & 1 & 0.49 \\
\hline Sylvia borin & & 1 & & 1 & 0.49 \\
\hline Sylvia atricapilla & & 2 & & 2 & 0.98 \\
\hline Phylloscopus collybita & & 1 & & 1 & 0.49 \\
\hline Phylloscopus sibilatrix & & 2 & & 2 & 0.98 \\
\hline Regulus sp. & 10 & & & 10 & 4.88 \\
\hline Muscicapa striata & & 2 & & 2 & 0.98 \\
\hline Ficedula sp. & & 2 & & 2 & 0.98 \\
\hline Erithacus rubecula & & 1 & 3 & 4 & 1.95 \\
\hline Aegithalos caudatus & 1 & & & 1 & 0.49 \\
\hline Parus major & & 2 & & 2 & 0.98 \\
\hline Periparus ater & 9 & 3 & 1 & 13 & 6.34 \\
\hline Cyanistes caeruleus & 4 & 2 & & 6 & 2.93 \\
\hline Poecile palustris & 1 & & & 1 & 0.49 \\
\hline Poecile montanus & & 1 & & 1 & 0.49 \\
\hline Paridae & & 1 & 4 & 5 & 2.44 \\
\hline Sitta europaea & & 2 & & 2 & 0.98 \\
\hline Certhia familiaris & 1 & 1 & 1 & 3 & 1.46 \\
\hline Troglodytes troglodytes & & 2 & 2 & 4 & 1.95 \\
\hline Fringilla coelebs & 3 & 3 & 4 & 10 & 4.88 \\
\hline Carduelis carduelis & 1 & & & 1 & 0.49 \\
\hline Carduelis cannabina & & 1 & & 1 & 0.49 \\
\hline Carduelis chloris & & 2 & & 2 & 0.98 \\
\hline Pyrrhula pyrrhula & & & 1 & 1 & 0.49 \\
\hline Coccothraustes coccothr. & 1 & 1 & & 2 & 0.98 \\
\hline Passeriformes indet. & 3 & & & 3 & 1.46 \\
\hline Aves & 34 & 35 & 17 & 86 & 41.95 \\
\hline Lacerta vivipara & & & 1 & 1 & 0.49 \\
\hline $\bar{\Sigma}$ & 127 & 44 & 34 & 205 & 100.00 \\
\hline
\end{tabular}

Mountain range / pohorie: 1 - Chočské vrchy Mts and Nízké Tatry Mts, Mikusek et al. 2001, 2 - Volovské vrchy Mts, Kamenný hrb and Čierna hora, Vysoký vrch, Pačenovský 1990, 3 Belianské Tatry Mts, Klaus et al. 1982. Numerical values in the Table are presented in absolute values.

from the breeding season of pygmy owls (VI-VII), 13 $(23.63 \%)$ of the 55 of the bird samples of prey analyzed were young birds. Juvenile birds found in the food, for example, were species of tits (Periparus ater, Poecile montanus) as well as, e.g., Sylvia atricapilla, Prunella modularis, Troglodytes troglodytes, Certhia familiaris and Fringilla coelebs.

A total of 582 individuals were determined in Slovakia from the food remains of $G$. passerinum (the submitted work, Klaus et al. 1982, Pačenovský 1990, 1993 , Mikusek et al. 2001, Šotnár 2009). Upon comparison of the results from the individual areas (Tab. 3) the high share of Microtus arvalis in the Chočské vrchy Mts in the non-breeding season is the most significant. Clethrionomys glareolus occurred in the pellets of $G$. passerinum with a higher domination than is the summary average in the mountain ranges which fringe the upper Nitra Region. In the Belianske Tatry Mts the rodent species Terricola subterraneus was the most abundant; in the mountain ranges of eastern Slovakia the yellow-necked mouse Apodemus flavicollis was the most frequently hunted, and from songbirds the coal tit Periparus ater. Among the songbirds hunted by breeding G. passerinum in the Považský Inovec Mts, the collared flycatcher Ficedula albicollis was the most abundant. The relative representation of species in the smaller food samples from the Západné Tatry Mts is similar to the Slovakia-wide average. Among the most abundant songbirds which are uniformly represented in all compared areas were: Regulus sp., Certhia familiaris, Poecile montanus and Cyanistes caeruleus.

While the northern population of $G$. passerinum lives in northern coniferous taiga, the Central European population of this species inhabits coniferous and deciduous forests. Its food was studied in the areas of the Czech Republic, Poland and Slovakia (Mikusek et al. 2001), in the German border region with the Czech Republic: the Bayerischer Wald Mts (Scherzinger 1974) and the Westerzgebirge Mts (Schönn 1976) and in Hungary in the border region with Slovakia in the Aggtelek Karst (Schmidt \& Pačenovský 2011). For a notable differentiation of the representation of prey in the samples from the non-breeding periods we calculate the data from the Chočské vrchy Mts separately from other results from Slovakia, which are from the breeding season. These indicate a higher abundance of several species of songbirds: Poecile montanus, Cyanistes caeruleus, Aegithalos caudatus, Sitta europaea, Ficedula albicollis and Phylloscopus collybita. From among rodents the share of Apodemus flavicollis in the food of G. passerinum is also higher in the Bayerischer Wald Mts and in the Stolowe gory Mts, and Clethrionomys glareolus in the Šumava Mts. Results from the Chočské vrchy Mts, 
Tab. 3. Comparison of the food of G. passerinum from different areas of Slovakia. Numerical values in the Table are presented in absolute value; positive and negative deviations (1+, 2+, and 1-, 2-) and are marked differences from the mean in the scope of a respective species, across locations. The diversity index H' is used, calculated according to the work of Shannon \& Weaver (1949).

Tab. 3. Porovnanie potravy G. passerinum z rôznych oblastí Slovenska. Číselné hodnoty v tabul'ke sú uvedené v absolútnych hodnodnotách, kladné a záporné odchýlky (1+, 2+ a 1-, 2-) sú významné odchýlky od priemeru v rámci toho istého druhu, naprieč lokalitami. Použitý je index diverzity H' je vypočítaný podl'a práce Shannon \& Weaver (1949).

\begin{tabular}{|c|c|c|c|c|c|c|c|c|}
\hline $\begin{array}{l}\text { samples / vzorky } \\
\text { taxa / taxón }\end{array}$ & 1 & 2 & 3 & 4 & 5 & 6 & $\sum$ & $\%$ \\
\hline Ficedula albicollis & $1+6$ & & & & & & 6 & 1.03 \\
\hline Periparus ater & & $1+21$ & 2- & 1 & 9 & & 31 & 5.33 \\
\hline Apodemus flavicollis & 1 & $1+18$ & 7 & & $1-$ & 1 & 28 & 4.81 \\
\hline Clethrionomys glareolus & 1 & $1-\quad 28$ & $1+56$ & 5 & 29 & 5 & 124 & 21.31 \\
\hline Terricola subterraneus & & $1-$ & 1 & $1+6$ & 6 & 1 & 14 & 2.41 \\
\hline Microtus arvalis & & $2-$ & $1-$ & & $2+45$ & 1 & 57 & 9.79 \\
\hline Erithacus rubecula & 1 & 7 & 8 & 3 & $1-$ & 1 & 20 & 3.44 \\
\hline Fringilla coelebs & 1 & 12 & 14 & 4 & $1-$ & 2 & 36 & 6.19 \\
\hline Regulus sp. & 3 & 7 & 5 & & 10 & 2 & 27 & 4.64 \\
\hline Certhia familiaris & 1 & 6 & 5 & 1 & 1 & 4 & 18 & 3.09 \\
\hline Poecile montanus & 3 & 6 & 8 & & & & 17 & 2.92 \\
\hline Cyanistes caeruleus & 2 & 4 & 6 & & 4 & & 16 & 2.75 \\
\hline Parus major & 2 & 5 & 7 & & & & 14 & 2.41 \\
\hline Troglodytes troglodytes & & 8 & 4 & 2 & & & 14 & 2.41 \\
\hline Phylloscopus collybita & & 5 & 8 & & & & 13 & 2.23 \\
\hline Sitta europaea & & 8 & 4 & & & & 12 & 2.06 \\
\hline Poecile palustris & & 2 & 7 & & 1 & & 10 & 1.72 \\
\hline Sylvia atricapilla & & 4 & 5 & & & & 9 & 1.55 \\
\hline Prunella modularis & & 3 & 4 & 1 & & & 8 & 1.37 \\
\hline Aegithalos caudatus & & 7 & & & 1 & & 8 & 1.37 \\
\hline Sorex araneus & & 1 & 1 & 1 & 4 & & 7 & 1.20 \\
\hline Sorex minutus & & 2 & & & 4 & & 6 & 1.03 \\
\hline Microtus agrestis & & & & 3 & 3 & & 6 & 1.03 \\
\hline Phylloscopus trochilus & & & 4 & & & 1 & 5 & 0.86 \\
\hline Phylloscopus sibilatrix & & 3 & 2 & & & & 5 & 0.86 \\
\hline Mammalia & 1- & $1-53$ & 77 & 16 & $1+93$ & 8 & 249 & 42.78 \\
\hline Aves & $1+21$ & $1+135$ & 111 & 17 & $1-\quad 34$ & 13 & 331 & 56.87 \\
\hline Reptilia & 0 & 0 & 0 & 1 & 0 & 0 & 1 & 0.17 \\
\hline Evertebrata & 0 & 0 & 1 & 0 & 0 & 0 & 1 & 0.17 \\
\hline $\bar{\Sigma}$ & 23 & 188 & 189 & 34 & 127 & 21 & 582 & 100.00 \\
\hline$\underline{\underline{H^{\prime}}}$ & 2.20 & 3.16 & 2.87 & 2.41 & 2.10 & 2.20 & 3.20 & \\
\hline
\end{tabular}

Samples / vzorky: 1 - Považský Inovec Mts (locality no. 1), 2 - Eastern Slovakia: Volovské vrchy Mts (oldest samples Kamenný hrb, Pačenovský 1990 and the newest from 2010-2014 no. 9-11 Kojšovská hol'a, Tupý vrch and Stará Voda) + Čierna hora (Vysoký vrch Mt, Pačenovský 1990) + Laborecká vrchovina Uplands (locality no. 12), 3 - upper Nitra: Súlovské vrchy Mts (locality no. 2) + Strážovské vrchy Mts (locality no. 3, 4) + Žiar Mts (locality no. 6, 7) + Vtáčnik Mts (location no. 5), 4 - Belianske Tatry Mts (older collections, Klaus et al. 1982), 5 - Chočské vrchy Mts and Nízké Tatry Mts (Mikusek et al. 2001), 6 - Západné Tatry Mts, Skorušinské vrchy Mts (locality no. 8).

with a higher dominance of rodents, are most similar to the data from the Bayerischer Wald Mts and from the Šmava Mts; a higher dominance of Microtus arvalis is also found in the Česko-Moravská vysočina Uplands. In the Šumava Mts the common shrew Sorex araneus and the lizard Lacerta vivipara also occur in the food more often. The field vole Microtus agrestis is also more abundantly represented in the Český les Mts and in the Stolowe gory Mts, where species of songbirds Poe- cile palustris, Troglodytes troglodytes and Saxicola rubetra are more often hunted. The highest share of songbirds is in the smallest samples from Bialowieza and Aggtelek, but also from the Westerzgebirge Mts, where species from the family Fringillidae are more abundant than in other comparable areas: Fringilla coelebs, Fringilla montifringilla, Carduelis spinus and Loxia curvirostra. Among the most abundant songbirds with equal representation in the compared samples 
of food from s G. passerinum in Central Europe are: Sylvia atricapilla, Lophophanes cristatus and Emberiza citrinella.

In association with the determining of the species Passer domesticus in the food of G. passerinum from one nest from the Strážovské vrchy Mts and with the assumption that this pygmy owl hunted within village territory, we cite a similar case described in the literature (Ferianc 1979): "Bethlenfalvy (1950) presents interesting data from the Vysoké Tatry Mts, namely that the Eurasian pygmy owl from the barns of local villages takes young birds away from the nests of barn swallow. He also personally observed that a Eurasian pygmy owl took young sparrows from the nest of a house martin".

In the conditions of the boreal taiga the food spectrum of the Eurasian pygmy owl differs significantly from that in Central Europe with respect to climatic and other differences, for example, the different zoogeographic environment. For comparison, in Finland on the basis of 2761 food samples determined in the breeding season, even bats were found in the food of pygmy owls, and in the breeding season mammals made up a higher share in the food $(54.2 \%)$ than in Central Europe, while birds made up only $44.0 \%$ (Mikkola 1983). Even the European perch (Perca fluviatilis) was found in the food, and during periods of higher population of voles their representation increased in the food to $78.8 \%$. From among birds Phylloscopus collybita, Carduelis spinus and Ficedula hypoleuca were the most abundant in the food, while Dendrocopos major, Turdus philomelos and Turdus iliacus were also found. In Sweden an even higher share of mammals $(63 \%)$ was found during breeding periods than in Finland and birds in a smaller proportion (37\%). In contrast, several authors in Norway found during the breeding season in smaller samples a very high share of birds in the food $(56 \%)$, with mammals making up only $27 \%$, the balance consisting in lizards (4\%) and undetermined amphibians $(13 \%)$. In Finland, it was also found that while birds at the start of the breeding season made up only $20 \%$ of the food, after the hatching of young, this proportion increased up to $71 \%$, which is explained by the significant drop in the population of small mammals during this period (all from Mikkola 1983).

In non-breeding seasons the pygmy owls in northern Europe prepare an abundant store of food and many authors investigated these stores. Voles were represented in Finland in the winter food almost equally as in breeding seasons (48\%); only birds were fewer $(32 \%)$, while the representation of common shrews rose to $12 \%$ (Mikkola 1983). The drop in the number of birds in the winter food of pygmy owls is explained by their scarcity, because with the arrival of winter the majority of birds migrate away. In different areas of Europe where the winter stores of pygmy owls were examined, the representation of micro-mammals fluctuated from $24.2 \%$ in Central Europe up to $74.7 \%$ in the area around Moscow. The representation of shrews fluctuated from $12.4 \%$ in Finland and $14.2 \%$ in Central Europe up to $44 \%$ in Norway and $51.6 \%$ in Bialowieza; the representation of birds fluctuated from $5.1 \%$ in the Moscow area up to $61.6 \%$ in Germany (Mikkola 1983). In Slovakia the representation of birds found in the winter samples (Mikusek et al. 2001) was 26.8\%; thus, it was more similar to the samples from Bialowieza than those from Germany, and the representation of shrews in winter samples from Slovakia (6.3\%) (Mikusek et al. 2001 ) is the lowest within Europe. In our results from the breeding period the share of shrews is even lower $(1.09 \%)$. In contrast, the representation of birds is one of the highest in Europe (65\%).

In the results on the winter food of the Eurasian pygmy owl from the northern border of the grounds from Russia from the White Sea birds made up $9.2 \%$ of the food, shrews only $5.0 \%$ and mammals up to $85.8 \%$ (Boiko \& Shutova 2006). In the countries of Central Europe the diversity of prey (H', Tab. 4) in the breeding period is higher than in non-breeding periods. This is supports the conclusions of Mikkola (1983), who stated: "the Eurasian pygmy owl is not a food specialist in this sense as are many other owls; it consumes a diverse range of food even in those years that are abundant in voles. The reason is that the productivity of habitats inhabited by pygmy owls is relatively poor, and therefore it hunts all available prey".

\section{C o n c l u s i o n}

In the set from 12 locations 10 species of mammals and 33 species of birds were found among the 377 individual prey samples. Among mammals, forest species of rodents predominated: Clethrionomys glareolus (22.8\%) and Apodemus flavicollis (6.6\%). The species Microtus arvalis $(2.7 \%)$ was less abundant than in the stores of food from the Chočské vrchy Mts (35.4\%). From the broad spectrum of songbirds, no species exceeded a share of $7 \%$. Species from the families Sylviidae, Turdidae, Paridae and Fringillidae were more numerous; from the more uncommon species of prey the species 


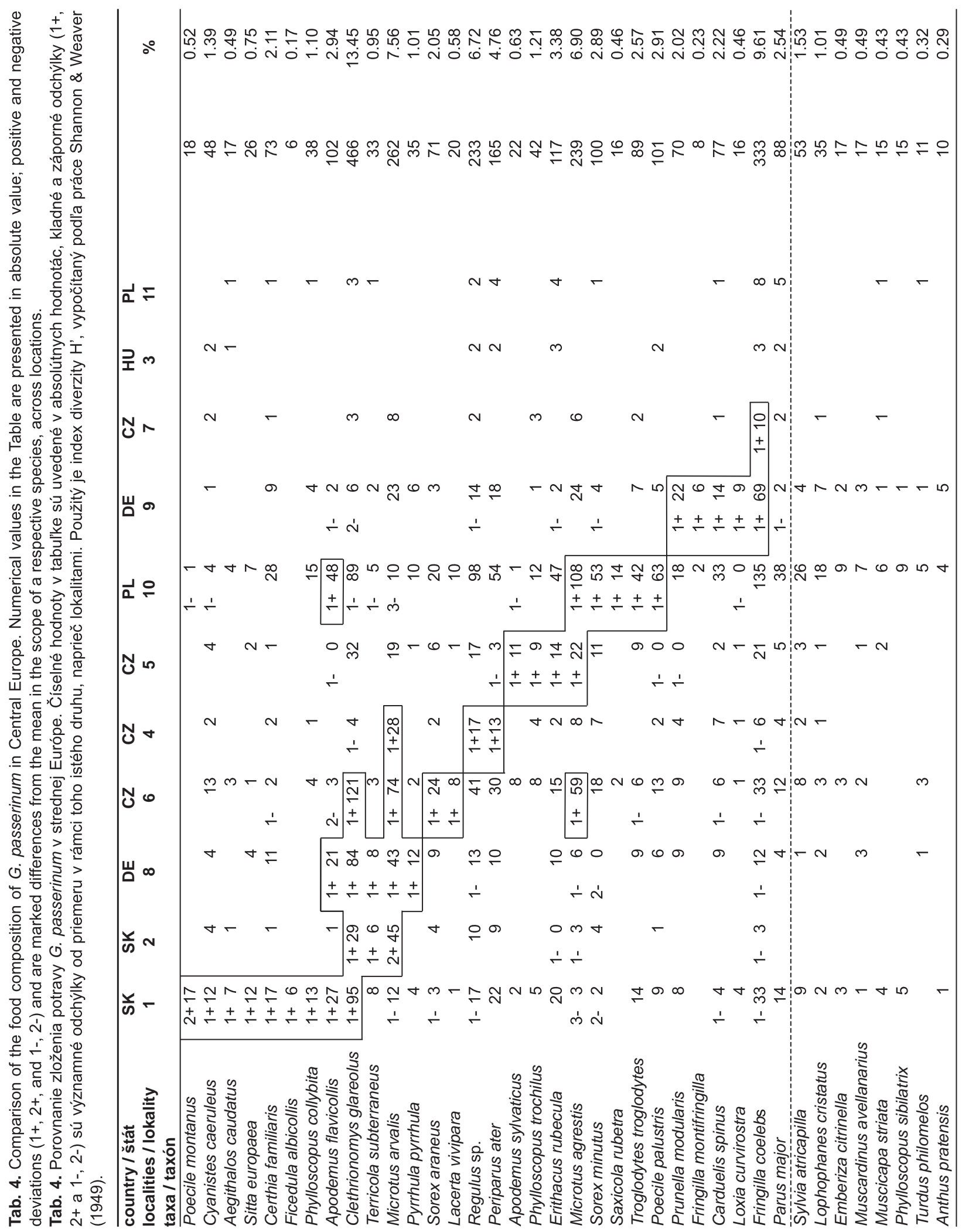




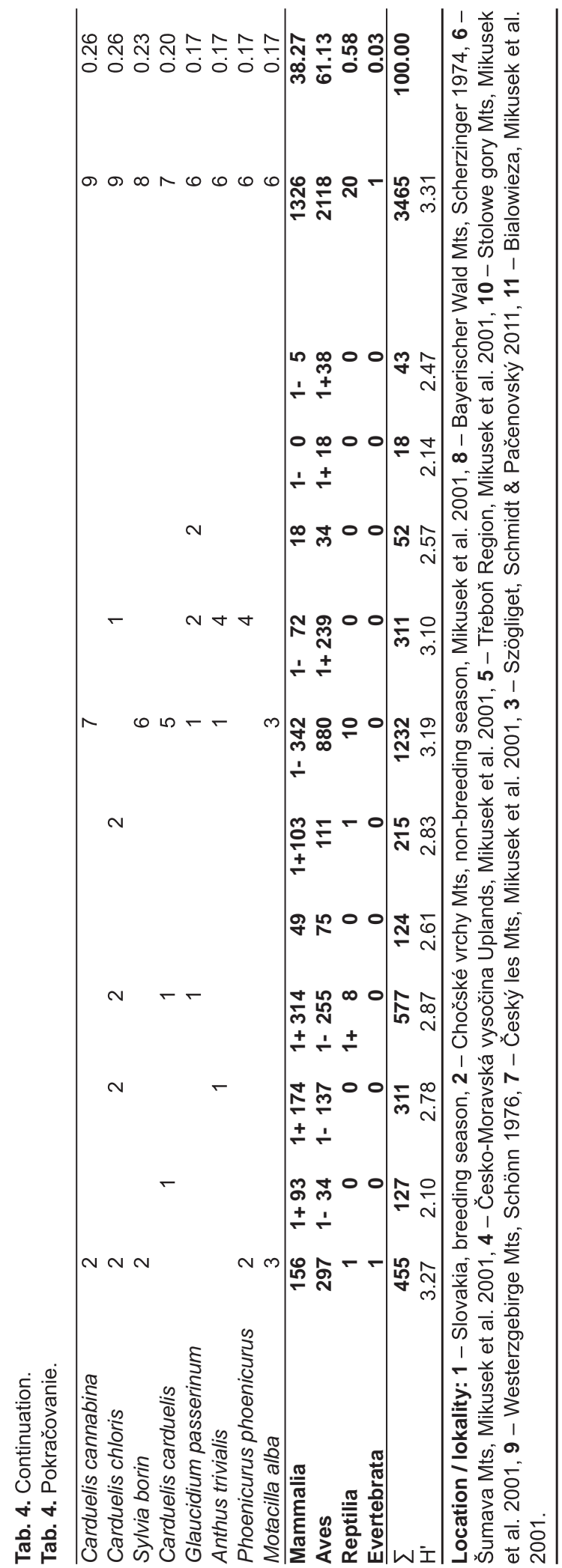

Phoenicurus phoenicurus, Motacilla alba, Carduelis cannabina, Dendrocopos minor and Passer domesticus were found. A high representation of juvenile birds was demonstrated in the bird's food during the breeding period. From food samples collected from 3 nests of Eurasian pygmy owls studied in eastern Slovakia (Volovské vrchy Mts) from the breeding season (June-July) in 2010-2014, $13(23.63 \%)$ of the 55 bird samples of prey analyzed were young birds. Juvenile birds found in the food, for example, were species of tits (Periparus ater, Poecile montanus) as well as the species Sylvia atricapilla, Prunella modularis, Troglodytes troglodytes, Certhia familiaris and Fringilla coelebs.

New data on the food of the Eurasian pygmy owl from Slovakia were assessed together with older published results of analysis of the food of Glaucidium passerinum from Slovakia from 1982-2001 (Chočské vrchy Mts and the Nízké Tatry Mts - Mikusek et al. 2001; Volovské vrchy Mts, Kamenný hrb and Čierna hora, Vysoký vrch - Pačenovský 1990, 1993; Belianské Tatry Mts - Klaus et al. 1982).

The results of analysis of 582 samples of food from Glaucidium passerinum from Slovakia (the submitted work, Klaus et al. 1982, Pačenovský 1990, 1993, Mikusek et al. 2001) show that birds with a proportion of $56.87 \%$ dominate in the food over mammals $(42.78 \%)$, while reptiles and invertebrates were represented consistently in a ratio of $0.17 \%$. In terms of weight categories species of prey in the range of 20-40 g predominated (e.g. Microtus arvalis, M. agrestis, Apodemus flavicollis, Fringilla coelebs); from bird prey, however lighter species, which can be put into the weight categories of 10-20 g, (e.g. Erithacus rubecula, Parus major, Phylloscopus collybita) were more predominant. The lightest prey fall into the category below 10 g (e.g. Regulus sp., Periparus ater, Sorex minutus, Lacerta vivipara). The largest prey found in Slovakia belong in the weight category over $40 \mathrm{~g}$ ( Coccothraustes coccothraustes) and represents heavier prey such as the pygmy owl itself, which was confirmed by different authors (Mikusek et al. 2001, del Hoyo et al. 1999, Mikkola 1983). The species Clethrionomys glareolus occurred with a higher than average dominance in pellets of G. passerinum in the mountain areas that fringe the region of the upper Nitra. In the Belianske Tatry Mts the most abundant rodent species was Terricola subterraneus; in the mountains of eastern Slovakia the yellow-necked mouse Apodemus flavicollis was the most often hunted, and from songbirds the coal tit Periparus ater. Among the songbirds hunted by 
breeding pygmy owls in the Považský Inovec Mts, the collared flycatcher Ficedula albicollis was the most abundant. Among the most abundant songbirds which are equally represented in all compared areas are: $R e g u$ lus sp., Certhia familiaris, Poecile montanus and Cyanistes caeruleus. Within Slovakia a significant difference is shown in the food structure during breeding and nonbreeding seasons. During breeding seasons in the 12 localities studied in the submitted work the share of birds in food achieved $65.0 \%$, versus the lower representation of mammals (34.8\%). In contrast to this, in non-breeding seasons in prey studied from winter stores (Mikusek et al. 2001) birds made up only $26.8 \%$, while mammals made up $73.2 \%$.

In summary it is possible to state that in Slovakia during the breeding season the Eurasian pygmy owl typically hunts songbirds (most frequently from the families Sylviidae, Turdidae, Paridae and Fringillidae) and small ground mammals (in particular from the families Soricidae, Muridae) usually up to a weight of $40 \mathrm{~g}$. In breeding seasons birds predominate over mammals in the food, with young birds forming a considerable portion of the bird prey. In non-breeding seasons the proportion of birds drops significantly, with mammals then becoming the favoured food.

\section{References}

Boiko N \& Shutova EV 2006: Diets of the pygmy owl Glaucidium passerinum and Tengmalm's owl Aegolius funereus in the gulf of Kandalaksha area, White Sea, 23-29. In: Koskimies P \& Lapshin NV (eds), Status of raptor populations in eastern Fennoscandia. Proceedings of the Workshop, Kostomuksha, Karelia, Russia, November 8-10, 2005. Karelian Research Centre of the Russian Academy of Science, Petrozavodosk.

del Hoyo J, Elliott A \& Sargatal J (eds) 1999: Handbook of the Birds of the World. Vol. 5. Barn owls to Hummingbirds. Lynx Edicions, Barcelona, 759.

Ferianc O 1979: Vtáky Slovenska 2 [Birds of Slovakia 2]. Veda, Bratislava, 470.

Klaus S, Klaus M \& Bräsecke R 1982: Beobachtungen an einem Brutplatz des Sperlingskauzes in dero Belaer Tatra (Belanské Tatry, ČSSR). Falke 29 (10): 330-336.

Mikkola H 1983: Owls of Europe. Poyser, Calton, 397.

Mikkola H \& Sackl P 1997: Pygmy owl Glaucidium passerinum, 406-407. In: Hagemeijer WJM \& Blair MJ 1997: The EBCC atlas of European breeding birds; their distribution and abundance. $\mathrm{T} \& \mathrm{AD}$
Poyser, London, 903.

Mikusek R, Kloubec B \& Obuch J 2001: Diet of the pygmy owl (Glaucidium passerinum) in eastern Central Europe. Buteo 12: 47-60.

Pačenovský S 2002: Kuvičok vrabčí / kuvik vrabčí [European pygmy owl], 364-367. In: Danko Ц̆, Darolová A \& Krištín A (eds), Rozšírenie vtákov na Slovensku. Birds distribution in Slovakia. Veda, Bratislava, 688. [In Slovak with English summary]

Pačenovský S \& Shurulinkov P 2008: Latest data on distribution of the pygmy owl (Glaucidium passerinum) in Bulgaria and Slovakia including population density comparison. Slovak Raptor Journal 2: 91-106. DOI: 10.2478/v10262-012-0023-5

Pačenovský S \& Šotnár K 2010: Notes on the reproduction, breeding biology and ethology of the Eurasian pygmy owl (Glaucidium passerinum) in Slovakia. Slovak Raptor Journal 4: 47-79. DOI: 10.2478/v10262-012-0046-y

Pačenovský S 1990: Rozbor potravy Glaucidium passerinum z dvoch hniezd na východnom Slovensku [Food analysis of Glaucidium passerinum from two east-Slovakian nests]. Tichodroma 3: 87-101. [In Slovak with English summary]

Pačenovský S 1993: K aktivite a spotrebe potravy kuvička vrabčieho (Glaucidium passerinum) [To activity and food consumption of pygmy owl (Glaucidium passerinum)]. Tichodroma 5: 17-21. [In Slovak with English summary]

Pačenovský S \& Kürthy A 1991: Nové výsledky výskumu rozšírenia kuvička vrabčieho (Glaucidium passerinum) na východnom Slovensku a niekol'ko poznámok $\mathrm{k}$ jeho etológii a hniezdnej bionómii [New results in research of the distribution of the pygmy owl (Glaucidium passerinum) on the territory of east Slovakia and few comments to its ecology and breeding biology]. Buteo 4: 63-72. [In Slovak with English summary]

Schmidt A \& Pačenovský S 2011: The breeding of pygmy owl (Glaucidium passerinum) on the Gömör-Tornai Karst. Aquila 118: 87-96. [In Hungarian with English summary]

Schönn S 1980: Der Sperlingskauz. Neue BrehmBücherei, Heft 513. Ziemsen Verlag, WittenbergLutherstadt, 123.

Šotnár K 2009: K etoekológii hniezdenia kuvička vrabčieho (Glaucidium passerinum) na hornom Ponitrí [On eto-ecology of the pygmy owl (Glaucidium passerinum) at the upper Nitra Region]. Vtáky 4(4): 4. [In Slovak] 